ORIGINAL ARTICLE

\title{
Child and family safety device affordability by country income level: an 18 country comparison
}

\author{
D Hendrie, T R Miller, M Orlando, R S Spicer, C Taft, R Consunji, E Zaloshnja
}

Injury Prevention 2004;10:338-343. doi: 10.1136/ip.2004.005652

See end of article for
authors' affiliations
$\ldots \ldots \ldots \ldots \ldots \ldots \ldots \ldots . . . . . .$.
Correspondence to:
Ted Miller, Pacific Institute
for Research and
Evaluation, 11710
Beltsville Drive, \#300,
Calverton, MD 20705,
USA; miller@pire.org

.......................

\begin{abstract}
Objective: To compare availability, urban price, and affordability of child/family safety devices between 18 economically diverse countries.

Design: Descriptive: urban price surveys by local safety organisations or shoppers.

Setting: Retail stores and internet vendors.

Main outcome measures: Prices expressed in US dollars, and affordability measured by hours of factory work needed to buy a child safety seat, a belt-positioning booster seat, a child bicycle helmet, and a smoke alarm.

Results: Prices of child and family safety devices varied widely between countries but the variation for child safety seats and bicycle helmets did not relate strongly to country income. Safety devices were expensive, often prohibitively so, in lower income countries. Far more hours of factory work were required to earn a child safety device in lower income than middle income, and middle income than higher income, countries. A bicycle helmet, for example, cost 10 hours of factory work in lower income countries but less than an hour in higher income countries. Smoke alarms and booster seats were not available in many lower income countries.

Conclusions: Bicycles and two-axle motor vehicles were numerous in lower and middle income countries, but corresponding child safety devices were often unaffordable and sometimes not readily available. The apparent market distortions and their causes merit investigation. Advocacy, social marketing, local device production, lowering of tariffs, and mandatory use legislation might stimulate market growth. Arguably, a moral obligation exists to offer subsidies that give all children a fair chance of surviving to adulthood.
\end{abstract}

$\mathrm{P}$ ersonal safety devices are proven unintentional injury prevention tools. Yet little is known about the availability, price, and affordability of these devices around the world. This is especially true of lower and middle income countries. This article compares such data for 18 economically diverse countries. It focuses on four child/family safety devices: car safety seats for infants and small children (child safety seats), belt-positioning booster seats for children who have outgrown child safety seats but do not yet fit in adult safety belts properly, bicycle helmets for children, and smoke alarms (which protect the entire family, not just children). These devices were chosen for five reasons. First, the focus is on child safety because of the common belief that all children deserve a fair chance, regardless of their income or place of birth. Child safety could be viewed as an entitlement. Second, the devices chosen have proven effectiveness in reducing serious unintentional injuries. ${ }^{1-5}$ These engineering solutions are effective against their target risks in countries of all income levels, although they may not target a country's main injury risks. Third, the devices make sense economically. At least in higher income countries, they are cost effective. ${ }^{6-10}$ Fourth, the devices are mainstream in higher income and some middle income countries where they are widely used. Finally, the devices have a market potential in some lower and middle income countries. They are companion devices that add safety to more expensive transportation vehicles and dwelling units that already are widely purchased in those countries.

The case for belt-positioning booster seats is weaker than for the other devices. Evidence of effectiveness is growing, ${ }^{2}$ but these seats are in the early stages of adoption and evaluation in higher income countries. Including them in the assessment yields insight into the influence of stage of adoption on availability and affordability.
Each section of this paper addresses device availability, then price, then affordability. Throughout, the term "cars" includes related private passenger vehicles.

\section{METHODS \\ Availability and price}

Information on the availability of the safety devices and their retail prices in urban areas in a convenience sample of 18 countries was collected by SAFE KIDS Worldwide affiliates, similar child safety organisations, or local shoppers. The objective was to identify a competitive retail price for local buyers, not the range of prices available or a bulk purchase price. The organisations, which canvassed prices in 12 countries, had expertise on child safety issues and training about safety devices. Local shoppers (three safety professionals and three residents with university degrees) canvassed prices and availability in a large city in each of the six remaining countries (Albania, Australia, Thailand, the United Kingdom, Venezuela, and Vietnam). In all cases, after written instructions, shoppers sought the lowest price devices that met local or international standards. Extreme prices were rechecked to assure data forms were not misread and prices had been canvassed appropriately. In the United States and Germany, the presence of both SAFE KIDs affiliates and local shoppers made it practical to compare pricing from these two sources. The prices proved consistent, which increases confidence in the comparability of the data. Prices were converted to US dollars using the current national exchange rate. ${ }^{11}$ To aid in data interpretation, when possible, place of device production was determined from package labels supplemented by shopper inquiries.

Countries were grouped by income level into lower income (wage below US\$3.00/hour), middle income (wage from US $\$ 3.00 /$ hour to US $\$ 9.99 /$ hour), and higher income (wage of 
$\$ 10.00 /$ hour and above). The groupings reflect clear clusters in the data; incomes in the middle income group actually range from $\$ 5.64-\$ 8.13$, with no countries near the extremes of this grouping.

\section{Affordability}

Prices also were expressed in factory hours of work required to generate enough income to buy each device. To compute this measure, device price was divided by pre-tax factory wages per hour (including supplements) in US dollars. The wage data were extracted from published sources. ${ }^{12}{ }^{13}$

The "hours of work" measure accounts for purchasing power variations across countries. Factory wages were used because of their international availability. Factory wages exceed the national average wages only modestly in higher income countries. In most lower income countries, however, large informal and rural sectors have much lower wages than the factory wage. Thus, the "hours of work" measure used in this study will lead to conservative differentials between higher and lower income countries and overstate all-household affordability in lower and middle income countries. Using factory wages appropriately focuses the affordability measure for these countries on people who may be able to afford some luxuries, those who are most likely to own motorized vehicles and represent the potential market for safety devices.

\section{RESULTS}

\section{Availability}

Device availability varied widely. All devices were readily available in the higher income countries (table 1). In China, the Philippines, Thailand, Vietnam, and Venezuela, these devices were luxuries sold only in stores that catered to

Table 1 Prices of safety devices in US dollars, 18 countries, 2002

\begin{tabular}{|c|c|c|c|c|}
\hline & \multicolumn{4}{|c|}{ Price (US\$) } \\
\hline & Car seat & $\begin{array}{l}\text { Booster } \\
\text { seat }\end{array}$ & $\begin{array}{l}\text { Bicycle } \\
\text { helmet }\end{array}$ & Smoke alarm \\
\hline \multicolumn{5}{|l|}{ Wage $<\$ 3.00 /$ hour } \\
\hline Albania & 49 & $\mathrm{~N} / \mathrm{A}$ & 12 & 13 \\
\hline China & 120 & 627 & 8 & 169 \\
\hline Philippines & 88 & 19 & 11 & 28 \\
\hline Thailand & 120 & 144 & 5 & $\mathrm{~N} / \mathrm{A}$ \\
\hline Venezuela & 85 & N/A & 14 & $\mathrm{~N} / \mathrm{A}$ \\
\hline Vietnam & 72 & 65 & 10 & 35 \\
\hline Group mean & 89 & 214 & 10 & 61 \\
\hline \multicolumn{5}{|c|}{$\begin{array}{l}\text { Wage } \$ 3.00-\$ 9.99 / \\
\text { hour }\end{array}$} \\
\hline Brazil & 90 & 200 & 35 & N/A \\
\hline New Zealand & 88 & 28 & 5 & 9 \\
\hline South Africa & 37 & 19 & 8 & 10 \\
\hline South Korea & 100 & 50 & 10 & $\mathrm{~N} / \mathrm{A}$ \\
\hline Group mean & 79 & 74 & 15 & 10 \\
\hline \multicolumn{5}{|c|}{ Wage $>\$ 10.00 /$ hour } \\
\hline Australia & 75 & 32 & 14 & 4 \\
\hline Austria & 140 & 12 & 8 & 21 \\
\hline Canada & 57 & 16 & 13 & 10 \\
\hline Germany & 70 & 20 & 15 & 14 \\
\hline Israel & 70 & 20 & 10 & 17 \\
\hline Japan & 158 & 19 & 34 & 50 \\
\hline United Kingdom & 60 & 28 & 16 & 6 \\
\hline United States & 50 & 20 & 10 & 5 \\
\hline Group mean & 85 & 21 & 15 & 16 \\
\hline Overall mean & 85 & 82 & 13 & 28 \\
\hline
\end{tabular}

N/A, not available

Source: Retail and internet stores, Universal Currency Converter." Notes: Prices were converted using current exchange rates without purchasing power parity correction. expatriates or high income families, if one could find them at all. In Hanoi in mid-2003, most expatriate shops sold bicycle helmets only for adults, not children. In Venezuela, the only smoke alarms available were intended for industrial use. South Korea did not sell smoke alarms. No devices except child safety seats were easily available in Brazil.

\section{Price}

Table l compares the prices of safety devices in 2002 US dollars. The mean price of child safety seats was similar in lower, middle, and higher income countries $(\$ 89, \$ 79$, and $\$ 85$ respectively). Nevertheless, prices ranged widely between countries. The mean price of bicycle helmets was lowest in lower income countries: \$10 compared with \$15 elsewhere. Booster seats and smoke alarms were unavailable or a costly luxury import in most lower income countries.

Prices were high in Japan, largely because stores stock only high end models. Indeed, high end bicycle helmets and child safety seats were available in places like the United States and Germany at prices similar to those in Japan.

\section{Affordability}

The price differentials between countries do not take account of the differences in purchasing power between countries. Table 2 controls for purchasing power differences by expressing the cost of child safety devices in hours of factory work needed to pay for them, using local hourly average factory wages (expressed in US dollars). Since lower and middle income countries have lower wages than higher income countries, safety device costs expressed in hours of work were more disparate than in nominal dollar prices.

In higher income countries, a factory worker needed 0.9 hours on average to earn a certifiably protective bicycle helmet. But in lower income countries, a comparable helmet cost the equivalent of 9.9 hours of work on average. For the other child safety devices, the work hour gradient was much steeper. For example, a child safety seat cost 5.0 hours of work in higher income countries compared with 10.5 hours in middle income countries and 79.0 hours in lower income countries. Moreover, the affordability of child safety seats between higher income countries varied, with three times as many work hours required to buy a seat in some countries than others. These seats were prohibitively expensive in many lower income countries, requiring weeks of factory work (up to three weeks in Thailand).

Table 3 rank orders wages and hours of factory work needed to buy the child safety devices by country. Work hours required to buy a safety device vary inversely with country income level. Parametric correlations and Spearman's rank correlations of work hours needed and wages all revealed significant negative associations at the 95\% confidence level. Only a few rankings of work hours required to buy a safety device crossed between the country income groupings. South Africa had notably reasonable pricing relative to wages, while purchasers in Japan needed extra hours of work to pay for high end goods.

\section{Used devices}

The prices in tables 1 and 2 were for new products. Some middle income countries in Europe have secondary markets for used child safety seats, and second hand shops sell them in many higher income countries. In Albania, used child safety seats imported from Italy are readily available for half the price of new ones (4l hours of factory work). However, such secondary markets cannot assure that used devices have not been recalled or damaged. Helmets that have been in crashes, for example, typically have compacted padding and may be cracked. ${ }^{14}$ 
Table 2 Hourly factory wage in 2000 in US dollars and factory hours of work needed to pay for four safety devices, 18 countries

\begin{tabular}{|c|c|c|c|c|c|}
\hline & \multirow[b]{2}{*}{ Hourly wage } & \multicolumn{4}{|c|}{ Factory hours of work needed to pay for safety devices } \\
\hline & & Car seat & Booster seat & Bicycle helmet & Smoke alarm \\
\hline \multicolumn{6}{|l|}{ Wage $<\$ 3.00 /$ hour } \\
\hline Albania & $\$ .59$ & 82.9 & N/A & 20.3 & 21.7 \\
\hline China & 2.26 & 53.1 & 277.4 & 3.7 & 74.5 \\
\hline Philippines & 1.90 & 46.2 & 10.0 & 6.0 & 14.9 \\
\hline Thailand & 0.65 & 122.4 & 146.9 & 4.9 & N/A \\
\hline Venezuela & 1.48 & 57.6 & N/A & 9.1 & N/A \\
\hline Vietnam & 0.98 & 111.6 & 101.2 & 15.2 & 54.3 \\
\hline Group mean & 1.31 & 79.0 & 133.9 & 9.9 & 41.4 \\
\hline \multicolumn{6}{|c|}{ Wage $\$ 3.00-\$ 9.99 /$ hour } \\
\hline Brazil & 7.21 & 12.5 & 27.7 & 4.9 & N/A \\
\hline New Zealand & 8.13 & 10.8 & 3.4 & 0.6 & 1.1 \\
\hline South Africa & 5.64 & 6.5 & 3.4 & 1.5 & 1.9 \\
\hline South Korea & 8.13 & 12.3 & 6.2 & 1.2 & N/A \\
\hline Group mean & 7.28 & 10.5 & 10.2 & 2.0 & 1.5 \\
\hline \multicolumn{6}{|c|}{ Wage $>\$ 10.00 /$ hour } \\
\hline Australia & 14.15 & 5.3 & 2.3 & 1.0 & 0.3 \\
\hline Austria & 19.46 & 7.2 & 0.6 & 0.4 & 1.1 \\
\hline Canada & 10.16 & 5.6 & 1.5 & 1.2 & 1.0 \\
\hline Germany & 22.99 & 3.0 & 0.9 & 0.7 & 0.6 \\
\hline Israel & 12.88 & 5.4 & 1.6 & 0.8 & 1.3 \\
\hline Japan & 22.00 & 7.2 & 0.8 & 1.5 & 2.3 \\
\hline United Kingdom & 15.88 & 3.8 & 1.8 & 1.0 & 0.4 \\
\hline United States & 19.86 & 2.5 & 1.0 & 0.5 & 0.3 \\
\hline Group mean & 16.04 & 5.0 & 1.3 & 0.9 & 0.9 \\
\hline Overall mean & & 30.9 & 36.7 & 4.1 & 12.6 \\
\hline \multicolumn{6}{|c|}{$\begin{array}{l}\text { N/A, not available. } \\
\text { Source: Retail stores, World Competitiveness Yearbook } 2000 \text { (hourly average manufacturing wage), Universal } \\
\text { Currency Converter." } \\
\text { Note: The hourly wage calculations ignore taxes. }\end{array}$} \\
\hline
\end{tabular}

\section{DISCUSSION}

This study offers the first comparison of the availability, urban retail price, and affordability of child safety devices in different countries. Booster seats and smoke alarms often were not readily available in lower income countries. The mean prices if devices were available were higher than in other countries. Mean prices for child safety seats and children's bicycle helmets proved similar regardless of

Table 3 Rank order of wages per hour of factory work and of factory hours of work needed to pay for safety devices, 18 countries

\begin{tabular}{|c|c|c|c|c|c|}
\hline & \multirow{2}{*}{$\begin{array}{l}\text { Rank order of } \\
\text { hourly wage }\end{array}$} & \multicolumn{4}{|c|}{$\begin{array}{l}\text { Rank order of factory hours of work needed to pay for safety } \\
\text { devices }\end{array}$} \\
\hline & & Car seat & Booster seat & Bicycle helmet & Smoke alarm \\
\hline \multicolumn{6}{|c|}{ Wage $<\$ 3.00 /$ hour } \\
\hline Albania & 18 & 16 & N/A & 18 & 12 \\
\hline Thailand & 17 & 18 & 15 & 13 & N/A \\
\hline Vietnam & 16 & 17 & 14 & 17 & 13 \\
\hline Venezuela & 15 & 15 & N/A & 16 & N/A \\
\hline Philippines & 14 & 13 & 12 & 15 & 11 \\
\hline China & 13 & 14 & 16 & 12 & 14 \\
\hline \multicolumn{6}{|c|}{ Wage $\$ 3.00-\$ 9.99 /$ hour } \\
\hline South Africa & 12 & 7 & 9 & 10 & 9 \\
\hline Brazil & 11 & 12 & 13 & 13 & N/A \\
\hline New Zealand & 9 & 10 & 9 & 3 & 6 \\
\hline South Korea & 9 & 11 & 11 & 8 & N/A \\
\hline \multicolumn{6}{|c|}{ Wage $>\$ 10.00 /$ hour } \\
\hline Canada & 8 & 6 & 5 & 8 & 5 \\
\hline Israel & 7 & 5 & 6 & 5 & 8 \\
\hline Australia & 6 & 4 & 8 & 6 & 1 \\
\hline United Kingdom & 5 & 3 & 7 & 6 & 3 \\
\hline Austria & 4 & 8 & 1 & 1 & 6 \\
\hline United States & 3 & 1 & 4 & 2 & 1 \\
\hline Japan & 2 & 8 & 2 & 10 & 10 \\
\hline Germany & 1 & 2 & 3 & 4 & 4 \\
\hline
\end{tabular}


country income group. Flat pricing means these devices are less affordable in countries with lower incomes.

\section{Market potential, availability, and return on investment}

Conceptually, local mass markets for auto and bicycle safety devices exist in many lower and middle income countries. Cars and motorized bicycles cost far more than companion devices that make these vehicles safer. Thus, households that own these vehicles and include children of appropriate ages represent potential safety device markets, families who can afford the devices and would benefit from having them. And the scattered data available on vehicle ownership show it is becoming widespread even in lower income countries, a conclusion readily confirmed by curbside observation. For example, in 2001, China had 540 million bicycles and 16 million cars. ${ }^{15}{ }^{16}$ In Manila, Sao Paulo, and increasingly even Ho Chi Minh City, car ownership was widespread. ${ }^{17} 18$ Durban, South Africa, a community of 2.5 million, had 400000 cars, with $25 \%$ of middle income households and even 50000 lower income households owning cars. ${ }^{19}$

With children worldwide increasingly riding in cars, the need for child occupant protection is not being met. But this unmet need may not be a major issue everywhere. Epidemiological data are critical when setting prevention priorities. For example, in Thailand, $65 \%$ of registered vehicles are motorcycles and two thirds of hospitalised and fatally injured child passengers and drivers were on a motorcycle. ${ }^{20}$ Only $6 \%$ were in cars when they were injured. Focusing on child occupant protection, therefore, will only address a small portion of a large problem.

Booster seats, which generally are in an early stage of adoption, predictably had penetrated into lower income countries less than child safety seats. They were much more expensive than in higher income countries and often unavailable. Comparison with child seats suggests maturation of the booster seat market in higher income countries probably will stimulate availability but only modestly reduce the price differential.

Even if safety devices were equally priced in all countries, the return on investment in them, and consequently their market potential, would differ. Because bicycles or motorised bicycles are the primary mode of personal transport in many lower income countries, a bicycle helmet user there presumably would wear the helmet for more kilometres per year than the typical user in higher income countries. Greater usage should increase the return on helmet investment. Yet these devices were not readily available in many lower income countries.

Smoke alarms had very limited availability in lower and some middle income countries. Despite the high rate of fire deaths in these countries, smoke alarms may not have broad residential applicability. They do not work in settings where open flames or wood/coal cook stoves give off smoke. Nevertheless, smoke alarms generally would cut the fire risks of the middle and upper classes, especially for the burgeoning urban apartment dwellers in many lower and middle income countries. They should be more available.

\section{Price differentials and their causes}

The price differentials observed are extremely wide considering that a large market potentially exists for these devices in some lower income countries. A major study weakness is the inability to explain these differentials fully. Without data relating to factors such as number of personal vehicles on the road, local device production, domestic device sales, and country of production of safety devices, it was difficult to disentangle the many possible reasons underlying price differentials.
Country of production appeared to play an important part in determining prices. Reliance on imports, which sometimes was associated with extremely limited availability, was a likely cause of the higher prices of booster seats and smoke alarms in most lower income countries and half the middle income countries. In contrast, New Zealand, South Africa and, for smoke alarms, Albania produced the devices locally or imported them from neighbouring countries at prices comparable to prices in higher income countries. Although Austria and Germany are adjoining European Union countries and should face minimal trade barriers, child safety seats (which are made in Germany) cost half as much in Germany as Austria but bicycle helmets (which are made in Austria) cost twice as much in Germany. Similarly, China, which manufactures most bicycle helmets sold in the United States, had a relatively low $\$ 8$ helmet price but limited availability. But these are not hard and fast rules. Prices in the United States are low despite a heavy reliance on imports. And China assembles many of the child seats and booster seats sold in the United States but prices of those devices in China are exorbitant.

Mandatory use laws have the proven ability to increase use in lower income countries. Motorcycle helmet use mandates, with related publicity and enforcement, for example, raised usage to $37 \%$ in Thailand and $88 \%$ in Indonesia (and reduced deaths and injuries). ${ }^{21}{ }^{22}$ The relatively low price of child bicycle helmets in Thailand most likely results from the active market the law created for helmets for motorized bicycle passengers.

Other likely contributors to the observed pricing differentials were lack of competition locally, differences in shipping costs and tariffs, and differences in device testing and performance standards. Additional influences on demand and price could include cultural patterns, public information campaigns about risks such as riding a bicycle without a helmet, differing risk levels between countries, and differing parental perceptions of injury risk relative to other potential harms.

Lack of active local mass markets for the devices and market segmentation could distort prices as well. For example, most American bicycle helmets were made in China. Those helmets cost as much at the factory door as they did on sale in a store in the United States. Although the marginal cost to increase local device production should be low if plants are not running at capacity 24 hours a day, a local, marginal price market had not emerged and queries to American plant owners revealed no interest in developing one. The entire production bulk was destined for export, not even leaving a small residual for a local elite market. If one could find a helmet in China that met standards, typically it was an adult helmet, and it was always priced near the average retail cost of export helmets.

\section{Research needed into the price differentials}

The large price differences observed do not result from study design flaws. While the local shoppers may not always have found the very lowest prices, they diligently identified locally competitive prices. Given the size of the observed differences, loosely consistent, inexpensive data collection methods were appropriate to initiate the policy debate. Future statistical probing of causation will require standardised data collection methods; systematic sampling of countries, retailers and internet vendors; investigation of price variability within country; and closer examination of where devices are manufactured.

Future research identifying the reasons underlying the observed price differentials could have important implications for safety policy. For example, would lobbying to remove trade barriers be fruitful if devices are not produced 
locally? Would local production make safety devices more affordable in lower and middle income countries?

Some promising natural experiments exist and merit careful evaluation. South Africa is locally producing effective safety devices affordably, and Asia Injury/SAFE KIDS Vietnam is producing quality motorbike helmets locally that soon may become part of school uniforms nationwide. SAFE KIDS coalitions in Brazil are taking a different approach, using education, demand, and advocacy to stimulate growth of local supply. With support from General Motors do Brazil and Johnson \& Johnson, media campaigns in three cities are boosting demand and less expensive, locally produced seats that meet international standards are starting to appear. India, Indonesia, Malaysia, New Zealand, Taiwan, and Thailand all mandate motorcycle helmet use. Evaluations of these natural experiments would provide useful information on the effectiveness of alternative approaches.

The experiences of higher and middle income countries with a high use of child safety devices may help to inform decisions about safety policy in lower and middle income countries. Strategies used in higher income countries may not always be practical in other countries. Worldwide, however, every country regulates the operation of motor vehicles on the grounds of safety. Mandating the use of complementary goods required to operate bicycles and motor vehicles safely quite possibly should be universal too.

\section{Affordability}

In some countries, given current prices, safety devices were clearly unaffordable for the vast majority of the population. Hours of factory work required to buy child safety devices were considerably more in lower income countries than in middle and higher income countries. The disparity existed for all the devices, although the difference was smaller for bicycle helmets. On average, a factory worker had to work 11 times as long to earn enough to buy a bicycle helmet in a lower income country than a higher income country. For a child seat, 16 times as many hours of work were required, for

\section{Key points}

- Safety devices were prohibitively expensive, if available, in lower income countries.

- A child's cycle helmet cost 10 hours of factory work in lower income countries but less than an hour in higher income countries.

- Lower income countries producing devices for export did not use excess plant capacity to produce devices for local consumption priced at marginal cost or even at export prices.

- Prices and affordability varied widely even among higher income countries.

- Judging from vehicles in use, latent markets for safety seats and bicycle helmets existed in some lower income countries but remained untapped.

- Many children face serious injury risk as a result of the income level of their household or country.

- Arguably a moral obligation exists to offer all children a fair chance of surviving to adulthood.

- The challenge is to develop policies to provide affordable risk protection to all children, regardless of household or country wealth. a smoke alarm 40 times as many, and for a booster seat, 100 times as many.

Although factors other than price affect use, availability and price are critical determinants of use. The impact of price is manifested primarily in terms of affordability. Affordability and availability differences clearly were related to country income group. In lower income countries, safety devices were luxuries only available in stores catering to expatriates or higher income shoppers. This means that children in these countries, especially middle and upper class children whose families own cars, have less risk protection than similar children in other countries. It raises important questions about equity in regards to injury risk. Policies to redress price differentials, mandate use, publicise need, or stimulate market development could possibly increase equity.

\section{Need for subsidies}

The need for device subsidies like those that corporate sponsors are offering on motorbike helmets for Vietnamese schoolchildren is an important issue. In the United States, the work hours required to buy a safety device are roughly 2.5 times as large for a minimum wage earner as for a factory worker and these differences create access problems. ${ }^{23}$ Although wage disparities are even larger in lower income countries, lower income households there might not reside and travel in ways that require safety devices. In the United States, government subsidies to solve income related access problems would yield a positive return on investment. ${ }^{9}$ Similar cost effectiveness analyses are needed in countries of all income levels, accompanied by analyses of device affordability, usage, and appropriateness by income class within country.

\section{Conclusion}

Wider use of the safety devices considered in this study could have a significant role in preventing childhood injuries. The challenge to injury prevention professionals is to identify the best way of promoting their use globally. The data reported in this study regarding availability and affordability patterns imply some children face serious risk as a result of the income level of their household or country. Arguably a moral obligation exists to offer all children a fair chance of surviving to adulthood by providing affordable risk protection devices, regardless of their household's or country's income status.

\section{ACKNOWLEDGEMENTS}

This study was funded in part by Johnson \& Johnson, the Alcoa Foundation, and Children's Safety Network Contract MCJ-240-030009 with the US Health Resources and Services Administration. This article would not have been possible without the enormous help of our local shoppers, many of whom work with SAFE KIDS Worldwide affiliates or similar organisations. We sincerely thank them.

\section{Authors' affiliations}

D Hendrie, School of Population Health, University of Western Australia, Nedlands, Australia

T R Miller, E Zaloshnja, Pacific Institute for Research \& Evaluation, Calverton, Maryland, USA

M Orlando, Center for Global Development, Washington, DC, USA

R S Spicer, Pacific Institute for Research and Evaluation, Bangkok, Thailand

C Taft, SAFE KIDS Worldwide, Washington, DC, USA

R Consunii, University of the Philippines, Manila, Philippines

\section{REFERENCES}

1 Zaza S, Sleet DA, Thompson RS, et al. Reviews of evidence regarding interventions to increase use of child safety seats. Am J Prev Med 2001;21(suppl 4):31-47.

2 Durbin DR, Elliott MR, Winston FK. Belt-positioning booster seats and reduction in risk of injury among children in vehicle crashes. JAMA 2003;289:2835-40. 
3 Thompson DC, Thompson RS, Rivara FP. Effectiveness of bicycle safety helmets in preventing head injuries. JAMA 1996;276:1968-73.

4 Scuffham P, Alsop J, Cryer C, et al. Head injuries to bicyclists and the New Zealand bicycle helmet law. Accid Anal Prev 2000;32:565-73.

5 Hall JR. A decade of detectors. Fire Journal 1985;79:37-43/78

6 Miller TR, Demes J. Child seats: how large are the benefits and who should pay? Child occupant protection. Warrendale, PA: Society for Automotive Engineers, 1993:81-90.

7 Hendrie D, Miller TR. Economic evaluation of injury prevention and control programs. In: McClure R, Stevenson M, McEvoy S, eds. The scientific basis of injury prevention and control. Sydney, Australia: IP Communications, 2004 (in press).

8 Miller TR, Levy D. Cost-outcome analysis in injury prevention and control: a primer on methods. Inj Prev 1997;3:288-93.

9 Miller TR, Levy DT. Reducing highway crash costs: the cost-outcome analyses In: von Holst H, Nygren A, Andersson A, eds. Transportation, traffic safety, and health: man and machine. Second International Conference, 1996. Brussels, Belgium: Karolinska Institute, Royal Institute of Technology, WHO Collaborating Center for Neurotrauma, Institute for Futures Studies, Volvo, 1998:171-98.

10 Miller TR, Levy DT. Cost-outcome analysis in injury prevention and control: eighty-four recent estimates for the United States. Med Care 2000;38:562-82.

11 Universal Currency Converter. Universal currency converter. XE.com. Available at: http://www.xe.com/ucc/convert.cgi laccessed September 2002)

12 Bureau of Labor Statistics. International comparisons of hourly compensation costs for production workers in manufacturing. Washington, DC: Bureau of Labor Statistics, 27 September 2002. Available at: http://www.bls.gov/ news.release/ichcc.toc.htm (accessed 12 March 2003).

13 Garelli S. World competitiveness yearbook 2000. Switzerland: IMD, Institute for Management Development, 2000
14 Smith TA, Tees D, Thom DR, et al. Evaluation and replication of impact damage to bicycle helmets. 37th Proceedings of the Association for the Advancement of Automotive Medicine 1993:143-55.

15 Haibro L. Still the bicycle kingdom. Beiijing review. Available at: http:// www.bireview.com.cn/200220/lhb-200220.htm (accessed 30 August 2002).

16 Madslien J. China car sector seeks world dominance. BBC news. Available at: http://news.bbc.co.uk/1/hi/business/2026707.stm (accessed 30 August 2002).

17 Asia Week. Asians hit the road, web edition. Asia Week. 6 July 2001 Available at: http://www.asiaweek.com/asiaweek/magazine/nations/ 0,8782,165900,00.html (accessed 17 March 2003)

18 Vietnam Data Communication Company. Drive to embrace car culture. Vietnam Data Communication Company. 30 July 2002. Available at: http:// www.vn-style.com/myhomeland/vietnaminclose-up/ chitiet.cfm?ID_Tin = 606\&CM = tb_vn_closeup (accessed 20 March 2003)

19 Durban Metro. Transportation: State, Durban Local Agenda 21. Cities Environmental Report on the Internet (CEROI). October 1999. Available at: http://www.ceroi.net/reports/durban/drivers/transport/state.htm (accessed 19 March 2003)

20 Santijiaraku S, Santikarn C, Spicer R, et al. Trends and epidemiology of childhood injury in Thailand. Paper presented at: 1st Asia-Pacific Injury Prevention Conference and 6th National Conference on Injury Prevention and Control, Australia: Perth, 16-18 March, 2003.

21 Ichikawa M, Chadbunchachai W, Marui E. Effect of the helmet act for motorcyclists in Thailand. Accid Anal Prev 2003;35:183-9.

22 Conrad P, Bradshaw Y, Lamsudin R, et al. Helmets, injuries and cultural definitions: motorcycle injury in urban Indonesia. Accid Anal Prev 1996:28:193-200

23 Mayer M, LeClere FB. Injury prevention measures in households with children in the United States, 1990. Advance data from vital and health statistics of the Centers for Disease Control and Prevention/National Center for Health Statistics. Hyattsville, MD: National Center for Health Statistics, 1994:15.

\section{An annual ritual: thanking reviewers}

As is customary, the December issue marks the time to express our gratitude to those who ensure that the quality of what we publish is of the highest possible caliber. We pride ourselves on obtaining usually prompt, detailed fair reviews. In the past 10 months - that is, to the day of writing and thus not complete for the calendar year -429 reviews were received from almost that number of people. (Several stalwarts did more than one; often several more.) Furthermore, many papers that are revised are returned to one or more of the original reviewers for further comments.

Remarkably, the average number of days to complete reviews was just over two weeks, resulting in $60 \%$ being returned "on time" - that is, within the three weeks we request. A further $19 \%$ were only one week late and fewer than $4 \%$ were more than two weeks late. Not at all bad for busy, in-demand folks. Readers and authors are indebted to all of you; the names are listed on our website (http://www.injuryprevention.com/supplemental) and I will try to remember to complete the list on 1 January 2005. I might add that most papers are reviewed by at least one member of the editorial board and they are now included on this list. Last year I did not include them and was reprimanded. 